This item was submitted to Loughborough's Research Repository by the author.

Items in Figshare are protected by copyright, with all rights reserved, unless otherwise indicated.

\title{
Science and engineering in digital capitalism
}

PLEASE CITE THE PUBLISHED VERSION

https://www.routledge.com/9781138922983

\section{PUBLISHER}

Routledge

VERSION

AM (Accepted Manuscript)

\section{PUBLISHER STATEMENT}

This work is made available according to the conditions of the Creative Commons Attribution-NonCommercialNoDerivatives 4.0 International (CC BY-NC-ND 4.0) licence. Full details of this licence are available at: https://creativecommons.org/licenses/by-nc-nd/4.0/

\section{LICENCE}

CC BY-NC-ND 4.0

\section{REPOSITORY RECORD}

Schiller, Daniel, and ShinJoung Yeo. 2019. "Science and Engineering in Digital Capitalism". figshare. https://hdl.handle.net/2134/23782. 


\title{
Science and Engineering In Digital Capitalism
}

\author{
Dan Schiller and ShinJoung Yeo
}

\begin{abstract}
During recent decades, at a cost that is reckoned in the trillions of dollars, digital systems and applications have been introduced across the length and breadth of the business system. ${ }^{1}$ This stupendous investment in ICTs, and the profit-strategies that it supports, constitute a basis for naming the contemporary political economy "digital capitalism.” Much the way that "industrial capitalism" extended beyond manufacturing to reorganize agricultural production and even information industries such as publishing, today digital capitalism has gripped every sector. Historically centered in the United States, yet transnational in scope, new network platforms are being innovated in order to extend and enlarge longstanding capitalist imperatives: exploitative wage relations; investment and product development decisions based on profit forecasts; ruthless pressures for cost-efficiency and growth (Schiller 1999, 2014; Wood 2003). This chapter foregrounds the place of science and engineering within this encompassing transition.
\end{abstract}

\section{Science and Capital: A Changing Historical Matrix}

Science has played a vital role in capitalist development historically. State policies to lure artisans possessing valuable knowledge and skills to one or another European country date back centuries. The economic historian Joel Mokyr credits a science-inflected "industrial enlightenment" with feeding the rise of industrial capitalism in $18^{\text {th }}$ century Europe (Mokyr, 2002). With the consolidation of this industrial capitalism, beginning late in the $19^{\text {th }}$ century, capital tried to systematize its reliance on scientific invention. Around such industries as submarine and terrestrial telegraphy, electrical power networks, industrial dyeing, and modern munitions, distinctive and generally new institutional practices were forged (Braverman, 1974; Nobel, 1977; Smith 1985; Hughes, 1983; Steckel, 1990).

The labor process of scientists working within the new corporate research laboratories shifted from individual and craft modes to systematized programs of collective research and testing (Nobel, 1977; Reich, 1985; Israel, 1992). Between 1900-1940, US industrial laboratories grew to over 2000 (Shapiro, 1993). Early science-based industries - chemical and electrical firms like General Electric (GE), DuPont and AT\&T - established their research arms and employed large numbers of scientists. In 1906, GE's laboratory had 102 staff, but it then quickly expanded to 555 by 1929 (Drahos and Braithwaite, 2003, p. 41). By the early 1950s, Bell Telephone Laboratories - the largest U.S. corporate R\&D facility - boasted a workforce of around nine thousand, inclusive of PhDs, lab technicians, and clerical staff (Gertner, 2012, p. 173-174).

Another feature was carried over and further extended: government support for the acquisition of economically valuable scientific knowledge. In the U.S., stretching across the nineteenth century, this had encompassed continental expeditions, often quasi-military in character, to survey land, climate, vegetation, and geology with an eye to farming, mining, and economic botany; by the early $20^{\text {th }}$ century, government's role also extended to systematic research in agriculture and other fields (Dupree, 1957; Goetzmann, 1978; Kloppenburg, 2004). Newly established public, as well as privately endowed, research universities hosted ever-more specialized inquiries - enabling corporations to keep an eye on the state of scientific advance and to cherry-pick from among those findings that were of interest - while educating cohorts of skilled scientific and technical labor: between 1880 and 
1920 the number of U.S. engineers skyrocketed, from 7000 to 136,000 (Lazonick, 2002, p. 199).

Another facet of the institutionalization of science and engineering as a foundation of hightech industrial capitalism was the expansion and systematization of the patent system. In line with their specific profit-strategies, corporately held patents enabled units of capital to develop and exchange "rights" to the "intellectual property" that scientists and engineers invented. ${ }^{2}$

Today, the institutional matrix that was established a century ago around scientific and technical labor is being readapted and modified in light of ongoing mutations in the political economy. The essential changes have been to bind science more directly to capitalist imperatives and to foreground information and communications as analytical touchstones.

According to 2014 Science and Engineering Indicators, by 2011, corporations conducted roughly $70 \%$ of US scientific R\&D and employed a comparable fraction of scientists and engineers - a substantial contrast to a half-century before, when $67 \%$ of US research was funded by the federal government (National Science Foundation, 2014; Schiller, 2013, p. 1318). Yet this picture is somewhat deceptive. While corporate capital absolutely dominates "development," the government actually claims a larger role than before in funding "basic" research. Between 1976 and 2009, notably, federal money provided two-thirds of university funding for research in computer science and electrical engineering (Singer 2014).

Notwithstanding this enormous public subsidy, academic science and engineering, which had chiefly been a supplier for capital, are gradually and incompletely - over decades - morphing into capital. Still nascent, this change signifies that university-based science and engineering themselves have partially internalized capitalist imperatives and merged more fully into the corporate sector. ${ }^{3}$ Contributing to this complex result have been altered patent licensing laws, the promotion of academic start-ups, and proliferating public-private partnerships. Decades ago, the U.S. government began to precipitate this metamorphosis of university science, via the Bayh-Dole Act of 1980, the Stevenson-Wydler Technology Innovation Act of 1980 and, Federal Technology Transfer Act of 1986, to promote commercial spin-offs of federally funded research. The Obama administration has broadly carried forward these initiatives under its "from lab to market" policy umbrella - which requires all federal executive agencies to set goals for speeding-up R\&D commercialization (Kalil and Choi, 2014). University administrators, legal staff, and professors now routinely collaborate to establish profit-making enterprises and to license university research to corporations. By one account, since Bayh-Dole in 1980, U.S. universities have created 10,000 companies (4,000 of which continued to operate in 2013). Although the income that they derive from commercial patent licensing remains modest - \$2.6 billion in 2013 compared to over \$140 billion federal R\&D funding in the same year (Sargent Jr., 2013) - research universities’ center-of-gravity has been substantially reconfigured around revenue-generation (Allen, 2014).

This sea change has simultaneously reset many science and engineering agendas, both so as to elevate conceptions of information and to assimilate information technology-based tools for sensing or probing, measuring, and processing scientific data. Though they must not be conflated, capital and the state have cooperated to enable and shape this development.

Government - and, especially, the military - has been the central axis of support for digitization since World War II (Flamm, 2018), and this remains true (see chapter 15). 
Involved are government contracts for research and equipment, and the opening-up of massive quantities of public data for capital to transform them into profitmaking products and services (White House Office of the Press Secretary, 2013).

In 2015, the U.S. Department of Defense (DOD) accounted for almost 50\% (\$66.091 billion in current dollars) of all federal R\&D spending (Hourihan and Parkes, 2015; Sargent Jr., 2015); meanwhile, DOD also spent more on IT than any other federal agency. According to the Office of Management and Budget (OMB), the 2016 budget requested a total of $\$ 86.4$ billion in IT spending - consisting of $\$ 49.1$ billion for civilian agency purposes and $\$ 37.3$ billion (43\%) for military and defense (Higgins, 2016). This does not include tens of billions of dollars in so-called "black budget" secret spending by intelligence agencies.

The U.S. government pivot toward information technology has reoriented the military toward "net-centric" systems for conducting war as well as to develop cyberwar, cyber command, cyber-security and signals intelligence capabilities. This changed the characteristics of military projects and generated torrents of R\&D dollars for the tech industries. Such fields as advanced algorithms, data analytics, data fusion, artificial intelligence and data mining today all much-promoted in the business press - are heavily reliant on military (hence state-) funding (Lutton, 2015; Shalal, 2015). One important military funder of leading-edge research for ICTs is the Defense Advanced Research Projects Agency (DARPA). For example, the agency increased its big data research funding by 69 percent over two years, from $\$ 97$ million in 2014 to more than \$164 million in 2016 (Lutton, 2015). DARPA also recently teamed up with a Silicon Valley consortium of 162 companies and universities including Boeing, General Motors, and Hewlett Packard, and funneled \$75 million in R\&D funding for wearable technologies (Worthington, 2015; Jacobsen, 2015).

The U.S. government role is, however, still more encompassing. President Obama came into office and hired the federal government's first-ever chief data scientist - a former PayPal and eBay executive, D.J. Patil. There followed an announcement that $\$ 200$ million would be allotted for a "Big Data Research and Development Initiative" led by the White House Office of Science and Technology Policy (OSTP), in order to spur investments of use in defense, health, energy, and other fields (Sottek, 2012). The government has called on "both the public and private sector to harness the power of data in ways that boost productivity, improve lives, and serve communities" (Executive Office of the President, 2014). More recently, the President's FY 2016 Budget allocated \$9.8 billion in discretionary funding for the U.S. Commerce Department to create conditions for economic growth with the agenda of promoting the "data-driven economy" (US Department of Commerce, 2015). The White House also released its "New Strategy for American Innovation" and vowed to invest in R\&D in the areas of advanced manufacturing, brain initiatives, precision medicine, selfdriving cars and "smart cities" to ensure that "the United States remains an 'innovation superpower”” (White House Office of the Press Secretary, 2015).

On the corporate side, the U.S. information industry has become a very influential patron of science: it is the largest sectoral R\&D investor in the U.S., conducting almost one-third of the R\&D total (Grueber and Studt, 2013). U.S. ICT companies also were expected to account for $57 \%$ of the industry's global R\&D expenditures in 2014 (Grueber and Studt, 2013).

Microsoft invested over $\$ 10$ billion in R\&D in 2014; closely following were Internet companies like Google and Amazon (Microsoft News, 2014). ${ }^{4}$ Korea-based Samsung spent even more than Microsoft (\$13 billion) but, though suggestive, this did not undercut U.S. preeminence in the information industry. For it is not coincidental that, boosted by an overall 
R\&D outlay that exceeds many small nations' overall gross domestic product, the U.S. information industry has been and remains the worldwide market leader.

Setting the U.S. agenda for science and engineering is a complex, multifaceted undertaking. One component of the institutional mechanism that performs this function is the President's Council of Advisors on Science and Technology (PCAST). Established by President George H.W. Bush in 1991, PCAST makes "policy recommendations in the many areas where understanding of science, technology, and innovation is key to strengthening our economy and forming policy that works for the American people." 5 In the Obama Administration, PCAST is flush with computer scientists, analytics specialists, biologists and aerospace engineers; and its members include both university scientists and corporate executives notably Eric Schmidt (Google's Executive Chairman and erstwhile CEO), and Craig Mundie (who left Microsoft in 2014 after 22 years). ${ }^{6}$ One PCAST member, Ed Penhoet, was a cofounder of Chiron, a pioneering biotech company, and serves both as an associate dean of biology at UC Berkeley and a director of Alta Partners, a life science venture capital firm. A 2015 report by a PCAST subcommittee holds that its aim is "ensuring leadership in federally funded research and development in information technology" (Executive Office of the President, 2015).

It needs to be stressed that R\&D in information systems and applications is not limited to IT companies. While ICT companies lead overall R\&D investment, often as a means of spearheading product- and market-development, they constitute just one aspect of a more encompassing movement. The generation of commodities that wire social and cultural spaces to the Internet is multi-sectoral - economy-wide. Once-discrete industries, from automobiles, manufacturing, finance, energy, and defense, to pharmaceuticals, agriculture, medicine, and education are aggressively investing in ICT R\&D, blurring the lines between industries as they incorporate and apply digital technologies in new profit projects.

\section{Science and Engineering in Corporate Commodification Projects}

Worldwide IT spending, in one estimate, came in at over $\$ 3.5$ trillion in $2015{ }^{7}$ The banking and "security" industries topped the IT spending list with over \$486 billion, closely followed by the manufacturing and natural resources industries with almost $\$ 477$ billion. ${ }^{8}$ The world's largest single non-IT-supplier spender on IT in 2014 was Walmart, with $\$ 10.16$ billion in outlays (followed by Bank of America, Citigroup, AT\&T and JP Morgan Chase) (Gagliordi, 2015). One of Walmart's primary business strategies has long centered on digitizing business data. In 1998, Walmart founder Sam Walton stated, "People think we got big by putting big stores in small towns. Really, we got big by replacing inventory with information.” During the 1990s, the company dominated retail markets by digitizing product inventories and sales data, transforming its supply chain in light of ceaseless updates to its knowledge of consumer sales trends (Schiller, 2007, p. 40, 211). Even so, over the last 10 years, Walmart has lost ground to Amazon - whose modernized online selling model is both equally data-dependent and even more cost-effective.

Having cut tens of thousands of union jobs, curbed employees' rights, and received billions of dollars in federal bailout money at the height of the 2008-9 crisis, the U.S. automobile industry also has invested heavily in network systems and applications. Automakers are bidding to renew profit growth via digital commodification, shifting their profit strategies from hardware to software and network-enabled devices. Vehicles are, increasingly, mobile services arrays (Schiller, 2014, p. 34-35). To restructure in this way, General Motors (GM) 
has built a \$130 million dollar data center modeled after those of Google and Facebook (Rosenbush and Bennett, 2013); invested about \$1 billion to expand its Warren Technical Center R\&D facility (Fisher, 2015); and hired an army of 8000 programmers to build custom software and internal infrastructure, seeking to hold off tech-industry interlopers such as Apple, Google, Oracle, Microsoft, and HP (Bennett, 2015). GM also has spent upwards of \$3 billion a year on IT services outsourced to other firms (Rosenbush and Bennett, 2015). GM's European competitor Volkswagen employs 9300 IT specialists and has poured about $€ 3.8$ billion ( $\$ 4.15$ billion) per year into information technology (Volkswagen, 2014). (It is difficult to imagine that Volkswagen's large IT capability was irrelevant to its installation of software to cheat pollution-emissions tests - an action that engulfed it in scandal late in 2015. ${ }^{9}$ )

Rooted in still another sector, agri-business giant Monsanto likewise expanded its field of profit-making by leveraging IT investments to establish data businesses. In 2013, Monsanto acquired the ability to perform big data analytics on a substantial scale, with an almost $\$ 1$ billion pay-out for a hyper-local data analytics company, Climate Corporation (McDonnell, 2014), a San Francisco tech firm founded by former Google employees. Climate Corporation, backed by Founders Fund, Khosla, Google Ventures, NEA, Index Ventures and Atomico, employs over 200 scientists to analyze fifty terabytes of weather data, extracted from government satellites, weather simulations, and soil observations (Specter, 2013). These practices feed into Monsanto’s program of generating and analyzing planting data to more closely control farming practices, throughout the entire cycle from planting to harvesting. Monsanto and farm equipment manufacturer John Deere have joined forces in this endeavor, as Deere tractors and other machinery are enhanced with software to collect micro-climateand detailed soil data directly from farmers. The data then are fed into Monsanto's data analysis application Climate Field View - and sold back to farmers. Cargill Inc. and DuPont Pioneer have matched these initiatives, by investing in sensor technology, data analytics, and wireless transmitters. However unfamiliar they might appear, these agro-companies are also increasingly information companies, rolling out data businesses around digital systems and services (Bunge and Tita, 2015).

In a bid to kick start its own lagging profit-growth, meanwhile, IBM has set its scientists to building a Merger and Acquisition (M\&A) tool that uses machine learning to conduct M\&As, to speed up the process and calculate risks by reducing human intervention; the company plans to sell this new tool as a service (Indap, 2016). To lower aircraft manufacturing costs, General Electric scientists are building backpack-sized jet engines by creating 3D models of parts as digital files and then transforming these files into objects via 3D printing (Knapp, 2015). Engineers at home automation company Nest Labs, which has been acquired by Google, work to develop profitable digital services on the basis of data generated by "smart" thermostats, fire alarms, security cameras, baby monitors, and other appliances (Marr, 2015).

Scientific and technical labor anchors these digital commodities and cost-efficiency strategies. The result is to place a growing premium on specialized information-oriented disciplines such as bioinformatics, data analytics, robotics, and artificial intelligence (AI). Some of these specializations have become veritable industries in their own right as they fuel disparate and suddenly substantial - profit projects. The global bioinformatics market, for example, is projected to reach $\$ 13.3$ billion by 2020 (MarketsandMarkets, 2015). AI systems for enterprise applications are expected to reach $\$ 11.1$ billion by 2024; the big data technology and services market is forecast to reach $\$ 46.8$ billion by 2019 (IDC, 2015). 
Within this sweeping reorientation toward a more networked-information-intensive political economy, however, the supply of prized scientific and engineering talent has become a significant issue.

\section{Reconstructing the Science and Engineering Labor Supply Chain}

For some time, the tech industry has led a larger corporate campaign to address what it sees as a shortage of skilled labor, charging that this deficit threatens to damage overall U.S. "competitiveness." Capital's demand is to boost the available supply of specialized scientific and technical labor - Science, Technology, Engineering, and Mathematics, or STEM labor to devise and manage and expand information-centric services and network applications. ${ }^{10}$

According to 2010 data from Science and Engineering Indicators 2014 (National Science Foundation, 2014 a), computer and mathematical sciences and engineering are the largest category of occupations within the S\&E field, with respectively 2.4 million and 1.6 million workers. Corporations are, by far, the largest employers of scientists and engineers, with a $70 \%$ share, followed by education with $19 \%$ and the government with $11 \%$ (NSF, 2014, b). The U.S. science and engineering workforce also is growing at a faster rate than the general labor force, especially in mathematics and computer-related occupations. ${ }^{11}$ Going forward, computer/mathematical scientist occupations are expected to expand further. ${ }^{12}$

Is the supply sufficient? Cisco predicts that approximately 220,000 new engineers will be needed globally every year for the next decade, simply to build what it hopes will be a trillion dollar business - the "Internet of Everything" (IoE) - based on machine-to-machine network connectivity, cloud computing, and network sensors (Krishnamurthi, 2014). The McKinsey consultancy forecasts that corporate demand for data scientists is likely to outrun supply for years, as between 140,000 and 190,000 data science positions in the U.S. are expected to be unfilled by 2018 (Orihuela and Bass, 2015). According to Forbes, in the year beginning June 2014, IBM alone advertised 2,307 positions requiring expertise related to big data (Columbus, 2015). Combing multiple labor markets, Amazon posted for more than 50 AI positions in the US and Europe, searching for PhDs focused on machine learning, information science and statistics (Mizroch, 2015). Microsoft and Google actually have acquired entire companies in order to gain access to their AI talent (Waters, 2016). While data scientists and data related expertise are concentrated in IT-related industries, once more the phenomenon is general: manufacturing, finance and insurance, and retail trade each draw in significant quantities of STEM labor (Columbus, 2015).

Resource-starved universities have quickly absorbed the lesson, and reoriented academic programs to train students for coveted STEM specializations. Promoting its new undergraduate degree program, for example, Ohio State University publicized “data scientist" as one of the top ranked jobs in America (Ohio State University News, 2016). An added advantage for obliging universities is the prospect of funding from companies at the forward edge of the profit system. As universities withdraw support for the humanities and languages, in turn, they lavish it on information-inflected specializations (American Academy of Arts \& Sciences, 2014). More than 40 universities - including Columbia, Cambridge, NYU, University of California Berkeley, Michigan - have created data science programs (Vanni, 2015) and duly gained financial support from tech giants like Google, Amazon, and Microsoft. When the University of Washington wanted to bring prominent artificial intelligence experts from Carnegie Mellon to boost its computer science department, the university sought help from the e-commerce giant Amazon, which obliged with a \$2 million 
grant for the appointment of “Amazon professorships” (Miller, 2013). This process is not free of contradiction: companies simultaneously battle to poach experts from academic communities around the world and demand that universities provide them with more appropriately skilled students (Mizroch, 2015).

Beyond reshaping educational institutions to prioritize STEM education, corporations also have addressed scientific labor-market shortages by looking beyond borders. Transnational companies are uniquely placed to tap talented scientists and engineers from across the globe. At the same time, they want to deploy STEM labor wherever their profit-strategies mandate including in the center of the global information industry, the United States.

Spearheaded by, but not limited to ICT firms, a quarter-century-long political fight erupted in the mid-1990s to increase the U.S. H-1B visa quota - the permits that enable U.S. firms to hire temporary foreign workers. During the years after the H-1B visa program launched, as part of the 1990 Immigration Act, the quota for these visas has fluctuated. The number increased throughout the dot.com boom in the late 1990s, from an initial limit of 65,000 to a peak of 195,000 under President Bill Clinton's American Competitiveness in the 21st Century Act (Wilson, 2008). After the dot.com bubble burst, however, the number reverted back to 65,000 , though the U.S. granted an additional 20,000 visas for those who had earned advanced degrees in U.S. universities - still insufficient, Bill Gates protested in 2008 (Wilson, 2008; Lee, 2008). More than one-third of H-1B visas are taken, significantly, by major multinational IT outsourcing companies like Cognizant Technology Solution, Tata Consultancy Services, and Infosys, which use them to supply temporary IT workers to U.S. firms at lower wages than they would otherwise have to pay (Hira, 2015). Google, Microsoft, Amazon, Intel and Facebook all avail themselves (Preston, 2015). By widening the pool of temporary workers and using these temps to perform "core” tasks (US Department of Labor Office of Foreign Labor Certification, 2014), the tech industry of course creates pressure to drive down the cost of its scientific and technical labor force. ${ }^{13}$ Partly for this reason, the influx of foreign-born STEM workers raises political sensitivities, albeit not on a scale comparable to that occasioned by immigration from war-torn Syria into Europe (Cooper, 2015).

These churning changes throughout science and engineering in digital capitalism, finally, also need to be situated within the latter's dynamic global context.

\section{Renewed Inter-Capitalist Competition and Inter-State Geopolitics}

Digital capitalism remains vulnerable to the violent shocks and downturns that have typified capitalist development throughout each of its earlier phases. As commodity production has been extruded and widened digitally, capitalism's crisis tendencies have reasserted themselves. The 2007 - 2008 financial and economic crisis ushered in the worst slump since the 1930s. In 2016, nearly nine years on, a new overhang of debt threatens global finance and what mainstream economists call "secular stagnation” has become chronic (Vinik, 2013).

Digital capitalism has been built largely within a U.S.-centric control structure: it privileges U.S. capital and is presided over by the U.S. state. However, as we have seen, it is an economy-wide phenomenon; and it has played out transnationally. Digital systems and applications constitute prized sources of growth in a political economy that is desperately short on it. As the "digital depression" has persisted, therefore, inter-capitalist rivalries over the science- and engineering-based information industries have correspondingly intensified. 
U.S. attempts to renew its dominance over the digital realm have encountered mushrooming resistance. Battles have broken out - chiefly in the sphere of economic diplomacy - to appropriate the coveted digital profit-sources.

The EU had lagged behind the U.S. in ICTs since World War II, indeed, in notable respects it had been rendered dependent. ${ }^{14}$ Well before the slump, the EU commenced fresh attempts to carve out room for European capital within a U.S.-centric system. Facing a prospective new "American challenge" during the early Internet era, the Lisbon Summit - held in 2000 at a European Council meeting - declared that its goal was for Europe to be "the most competitive, knowledge-based economy in the world by 2010” (Padoan, 2009). In 2002, at the Barcelona Summit, EU member states pledged to invest 3\% of their respective GDP's toward R\&D (Padoan, 2009). The target had not been reached by 2016, partly because of the severe austerity measures put in place across Europe after the 2008 economic crisis. However, in 2010, the executive arm of the EU, the European Commission (EC), did launch its Europe 2020 Strategy (European Commission, 2016). Its so-called "Digital Agenda” sought to boost Europe's digital economy and to emphasize " seven pillars” as sites of growth - including increased information infrastructure capacity, greater R\&D investment in ICTs, and measures to promote ICT employment.

Yet the EU continues to struggle. Its injection of an R\&D funding program to develop a European version of Google led by Germany and France has not been successful (Hern, 2015). Moving onto its back foot, the EU continues to push back against U.S. science-based Internet companies. An antitrust case against Google is ongoing, the safe harbor agreement allowing the movement of data from the EU to the U.S. has been thrown out, a "Google Tax" has been imposed, and a competition inquiry has been launched into Amazon's dominance in the ebook market (Couturier, 2016; Bowers, 2015, 2016)

More impressive is the pushback from China, though this broad and multifarious initiative needs to be carefully situated. As of 2014, China's R\&D outlay of $\$ 203.7$ billion already exceeded Japan's and was about to pass that of the EU (gbtimes, 2015). According to the 2014 Science, Technology and Industry Report from the Organization for Economic Cooperation and Development (OECD), Chinese universities produced over 27,000 doctorates in science and engineering in 2011, while the U.S. produced 24,792 doctorates. While the US still accounts for the largest number of top-cited publications across all disciplines, China is the second-highest producer of top-cited academic articles in seven major disciplines - Materials Science, Chemistry, Engineering, Computer science and Chemical engineering, Energy and Mathematics (OECD, 2015). In 2013, moreover, China garnered 32.1\% of the world's total patents - the U.S. had 22.3\% and European Patent Office (EPO) shared 5.8\% (World Intellectual Property Organization (WIPO), 2014). In 2014, China's Huawei, the largest telecommunications equipment manufacturer in the world, filed the largest number of international patents, beating out U.S. tech company Qualcomm (Jerin, 2015).

This should not be seen as a function merely of China's "rise.” China's growing prominence in science and technology actually possesses an ambiguous meaning. It testifies both to China's re-insertion into a U.S.-led trans-nationalized digital capitalism, and to Chinese leaders' successes in reorganizing this system, better to foreground the expansionary needs and demands of Chinese capital, and Chinese military strategy. 
China's effort to situate science-based digital systems and applications industries at the center of its overall economic development was initially based significantly on foreign direct investment (FDI). Through tax rebates, lower tariffs, and R\&D subsidies, China encouraged foreign capital to invest in domestic high tech industries and, specifically, in R\&D centers to seed the development of its domestic ICT industry.

Foreign firms invested considerably in China-based R\&D, in particular, in electronics, telecommunications, biotechnology, pharmaceuticals, chemicals and automobiles (Tselichtchev, 2011). Their goal was at once to tap into the growing Chinese local market and to access an expanding pool of well-trained but less-highly paid scientists and engineers.

Even before China's accession to the World Trade Organization (WTO), major transnational corporations (TNCs) were thronging into the Chinese market, establishing R\&D centers and joint-ventures with local firms, notwithstanding that China's party-state imposed requirements for technology transfer and training of local staff. China's foreign capital driven R\&D policy was a key part of its economic strategy to develop its domestic information market and, ultimately, to help domestic units of capital to transnationalize. As of 2013, there were over 1,600 R\&D centers in China, and among them at least 1,300 were affiliated with transnational corporations (Marro, 2015).

U.S. capital played a particularly significant role in China's R\&D activities. Since 2007, over 40 percent of China's total FDI in R\&D has come from the U.S., which is the largest R\&D exporter to China (China Daily, 2015). China indeed attracts a greater amount of foreign direct investment in R\&D projects than the U.S. itself: between January 2000 and December 2014, China drew 88 R\&D laboratories (greenfield R\&D) from foreign companies involving $\$ 5.5$ billion in capital investment, more than twice the amount of U.S.'s 91 R\&D projects (Fingar, 2015).

Targeted science and technology R\&D has become a key aspect of the Chinese party-state's decision to prioritize information, culture and the Internet as "pillar industries" (Hong, in press and Shafaeddin, 2012, p. 252). This strategy has succeeded in aiding an impressive list of China-based companies in digital systems and applications markets: China Mobile, Baidu, Alibaba, Tencent, Xiaomi, Huawei, Lenovo, and others. These companies either already exhibit, or else harbor, transnational aspirations and, akin to their U.S. counterparts, they cultivate ties with a much wider group of industrial and government users of networked systems and services.

Chinese companies correspondingly have established R\&D activities in other countries, especially in the U.S. - San Jose, Detroit, and Dallas each host Chinese-funded R\&D centers. China's tech firms Alibaba, Baidu, and ZTE Corp have built a U.S. presence; Huawei alone has erected six U.S. research centers. The U.S. government has imposed persistent pressure on Huawei, on grounds of "security concerns" about "cyber-espionage," to the point that the company announced a momentary withdrawal from the US market (Tiezzi, 2013). However, for Huawei - which doubled its R\&D to \$6.6 billion in 2014, passing Apple (Truong, 2015) the U.S. market is too important to neglect. The Internet equipment maker has reentered the U.S. with a new mobile handset, and has signaled a plan to compete with Apple, Samsung and Google.

Despite heavy participation by foreign capital in its own domestic market, China's digitallyinflected economic policies and its ready supply of science and engineering labor have helped it to develop into the world's second-largest national information and communication market. 
This concurrently enables China-based companies to project their interests throughout an increasing portion of the transnational political economy. This result constitutes a farreaching structural change. Though it is still incomplete and there remain many contingencies, China's build-up in digital systems and applications poses a destabilizing challenge to what has been a U.S.-structured digital capitalism.

U.S. leaders are keenly cognizant of this. Internationally, the U.S. state and U.S. capital seek to shore up their advantage and to renew digital dominance. One contributing initiative is to push for greater control over scientific knowledge by expanding the existing, U.S.-centric, intellectual property regime. The U.S. government has pressed to institute regional trade agreements that would allow it to shape rules for patents, copyrights and trademarks. In 2015, the U.S. reached agreement on the secretively negotiated Trans-Pacific Partnership (TPP) with 11 other Asia-Pacific countries, ${ }^{15}$ one effect of which would be to exclude China from the rulemaking structure covering forty percent of the world's economy. The U.S. concurrently negotiated with the EU on the Transatlantic Trade and Investment Partnership (TTIP). For the TPP, the U.S. pushed hard to adopt still more restrictive IP rules, to privilege already heavily advantaged U.S. capital while preempting its competitors. For instance, the U.S. Trade Representative campaigned to secure twelve years of exclusive protection for biologics data - on behalf of the U.S. pharmaceutical and biotechnology industry and to the detriment of people in less-developed countries and of poor people everywhere. Facing opposition from other countries, the U.S. was, however, compelled to acquiesce to a shorter 5 -year limit with an additional 3 years of “comparable” protection (Bradsher and Pollack, 2015).

With the U.S. struggling to preserve its advantageous position as geopolitical conditions change and as China continues to reintegrate into digital capitalism, science once again demarcates a battleground on which capital and capitalist states vie with one another. It remains an open question whether China will, or could, mount a wide-ranging challenge to the existing U.S.-centric organization of digital capitalism. Also open, by contrast, is whether an oppositional movement may coalesce and gain strength sufficient to push the international community to adopt a different, more beneficial and just agenda. In the absence of such a movement, however, it is a near-certainty that digital capitalism will exhibit stepped-up intercapitalist competition. How these rivalries may impinge on what is already a turbulent political economy cannot be foretold.

\section{References}

Allen, J. (2014) 'Does University Patent Licensing Pay Off?' IPWatchdog, 27 January, http://www.ipwatchdog.com/2014/01/27/does-university-patent-licensing-pay-off/id=47655/.

American Academy of Arts \& Sciences (2014) The State of the Humanities: Funding 2014, http://www.humanitiesindicators.org/binaries/pdf/HI_FundingReport2014.pdf.

Bennett, J. (2015) 'Why GM Hired 8,000 Programmers,' Wall Street Journal, 17 February, http://www.wsj.com/articles/gm-built-internal-skills-to-manage-internet-sales-push1424200731.

Bowers, S. (2015) 'European commission to investigate Amazon's ebook dominance,' Guardian, 11 June, http://www.theguardian.com/technology/2015/jun/11/europeancommission-investigate-amazon-ebook-dominance. 
Bowers, S. (2016) 'French finance minister blasts UK's £130m Google tax deal,' Guardian, 2 February 2016, http://www.theguardian.com/technology/2016/feb/02/french-financeminister-blasts-mrcs-130m-tax-deal-with-google;

Bradsher, K. and Pollack, A. (2015) 'What Changes Lie Ahead From the Trans-Pacific Partnership Pact,' New York Times, 5 October, http://www.nytimes.com/2015/10/06/business/international/what-changes-lie-ahead-fromthe-trans-pacific-partnership-pact.html.

Bowers, S. (2015) 'European commission to investigate Amazon's ebook dominance,' Guardian, 11 June, http://www.theguardian.com/technology/2015/jun/11/europeancommission-investigate-amazon-ebook-dominance.

Braverman, H. (1974) Labor and monopoly capital the degradation of work in the twentieth century, New York: Monthly Review Press.

Bunge J. and Tita, B. (2015) 'Monsanto, Deere Join Forces Over Data Services,' Wall Street Journal, 5 November 2015, http://www.wsj.com/articles/monsanto-deere-join-forces-overdata-services-1446580917

China’s R\&D spending up 10\% in 2014 (2015) gbtimes, 23 November, http://gbtimes.com/china/chinas-rd-spending-10-2014

Cooper, B. (2015) 'With winter fast approaching the refugee crisis could become a medical disaster,' Open Democracy, 2 December, https://www.opendemocracy.net/can-europe-makeit/benedict-cooper/with-winter-fast-approaching-refugee-crisis-could-become-medical-.

Couturier, K. (2016) 'How Europe Is Going After Google, Amazon and Other U.S. Tech Giants,’ New York Time, 19 May, http://www.nytimes.com/interactive/2015/04/13/technology/How-Europe-Is-Going-AfterU.S.-Tech-Giants.html?_r=0

Data Scientist is 'Best Job’ in 2016 (2016) Ohio State University, 20 January https://dataanalytics.osu.edu/news/data-scientist-best-job-2016.

Davenport C. \& Hakim, D. (2016) “US Sues Volkswagen in Diesel Emissions Scandal,” New York Time, 4 January, http://www.nytimes.com/2016/01/05/business/vw-sued-justicedepartment-emissions-scandal.html?_r=0.

Dickson, D. (1984) The New Politics of Science, New York: Pantheon.

Drahos, P. \& Braithwaite, J. (2003) Information feudalism: who owns the knowledge economy? New Delhi: Oxford University Press.

Dupree, A. H. (1957) Science In the Federal Government: A History of Policies and Activities to 1940, Cambridge, Mass.: Belknap Press of Harvard University Press. 
European Commission (2016), Europe 2020 strategy: Digital Agenda for the Europe: Pillar VII: ICT-enabled benefits for EU society, 22 February, https://ec.europa.eu/digitalagenda/en/our-goals/pillar-vii-ict-enabled-benefits-eu-society.

Executive Office of the President (2015) President's Council of Advisors on Science and Technology, "Report to the President and Congress Ensuring Leadership in Federally Funded Research and Development in Information Technology,"

https://www.whitehouse.gov/sites/default/files/microsites/ostp/PCAST/nitrd_report_aug_201 5.pdf.

Executive Office of the President, (2014) 'Big Data: Seizing Opportunity Preserving Value,' https://www.whitehouse.gov/sites/default/files/docs/big_data_privacy_report_may_1_2014.p df.

Executive Office of the President (2015) 'Report to the President and Congress Ensuring Leadership in Federally Funded Research and Development in Information Technology,' President's Council of Advisors on Science and Technology, https://www.whitehouse.gov/sites/default/files/microsites/ostp/PCAST/nitrd_report_aug_201 5.pdf.

Fingar, C. (2015) 'China passes US in race for FDI in research and development,' Financial Times, 22 July, http://www.ft.com/intl/cms/s/3/241d9366-3058-11e5-91aca5e17d9b4cff.html\#axzz3sRhsbjUX.

Fisher, A. (2015) 'Why General Motors is scrambling to find tech workers,' Fortune, 26 May, http://fortune.com/2015/05/26/gm-tech-workers-hiring/.

Flamm, K. (1988) Creating the computer: government, industry, and high technology, Washington, D.C.: Brookings Institution.

Gagliordi, N. (2015) 'Walmart tops IDC list of world's biggest IT spenders,' ZDnet, 7 April, http://www.zdnet.com/article/walmart-tops-idc-list-of-worlds-biggest-it-spenders

Gertner, J. (2012) The Idea Factory: Bells Labs and the Great Age of American Invention, New York: Penguin Press.

“Global Intellectual Property Filings Up in 2013, China Drives Patent Application Growth," World Intellectual Property Organization, 16 December 2014, http://www.wipo.int/pressroom/en/articles/2014/article_0018.html.

Goetzmann, W. H. (1978) Exploration and Empire: The Explorer and the Scientist in the Winning of the American West, New York: W.W. Norton.

Grueber, M. \& Studt, T. (2013) Battelle-2014 Global R\&D Funding Forecast. R\&D Magazine, https://www.battelle.org/docs/tpp/2014_global_rd_funding_forecast.pdf

Hern, A. (2015) 'In Search of a European Google,' Guardian, 6 December, http://www.theguardian.com/technology/2015/dec/06/europe-google-silicon-valley-digitalindustry. 
Higgins, J. (2015) 'Proposed 2016 Federal Budget Plumps IT Spending by \$2B,’ Ecommerce Times, 11 March, http://www.ecommercetimes.com/story/81805.html?rss=1.

Hira, R. (2015) 'New Data Show How Firms Like Infosys and Tata Abuse the H-1B Program,’ Economic Policy Institute, 19 February, http://www.epi.org/blog/new-datainfosys-tata-abuse-h-1b-program/.

Hong, Y. (In Press) Networking the Nation, University of Illinois Press.

Hourihan M. \& Parkes, D. (2016) "Federal R\&D in the FY 2016 Budget: An Overview," American Association for the Advancement of Science, http://www.aaas.org/fy16budget/federal-rd-fy-2016-budget-overview

Hughes, T. (1983) Networks of Power: Electrification In Western Society, Baltimore: Johns Hopkins.

Indap, S. (2016) 'IBM bets on mergers and algorithms for growth,' Financial Times, 12 January, http://www.ft.com/intl/cms/s/0/11010eea-ae5f-11e5-993bc425a3d2b65a.html\#axzz3xyvWvOQd.t.

Israel, P. (1992) From Machine Shop to Industrial Laboratory: Telegraphy and the Changing Context of American Invention, 1830-1920, Baltimore: Johns Hopkins University Press.

Jacobsen, A. (2015) The Pentagon's Brain: An Uncensored History of DARPA, America's Top Secret Military Research Agency, New York: Little, Brown.

Jerin, M. (2015) 'China's Huawei top international patent filer ahead of Qualcomm and ZTE,' International Business Times, 21 March 2015, http://www.ibtimes.co.uk/chinas-huawei-top-international-patent-filer-ahead-qualcomm-zte1492947.

Kalil, T. \& Charina Choi, C. (2014) 'From Lab to Market: Accelerating Research Breakthroughs and Economic Growth,' Office of the US President, 14 March, https://www.whitehouse.gov/blog/2014/03/14/lab-market-accelerating-researchbreakthroughs-and-economic-growth.

Kloppenburg, J. (2004) First the Seed: The Political Economy of Plant Biotechnology, 14922000, Madison, Wis.: University of Wisconsin Press.

Knapp, A. (2015) ‘GE Engineers 3D-Printed A Working, Mini Jet Engine,’ Forbes, 11 May, http://www.forbes.com/sites/alexknapp/2015/05/11/ge-engineers-3d-printed-a-working-minijet-engine/\#f5f1056246d5.

Krishnamurthi, S. (2014) 'More education needed to realize the Internet of Everything,' Network World, 10 December, http://www.networkworld.com/article/2857890/internet-ofthings/more-education-needed-to-realize-the-internet-of-everything.html.

Lazonick, W. (2002) American corporate economy: critical perspectives on business and management, London: Routledge. 
Lee, T. (2008) 'Gates to Congress: Microsoft needs more H-1B visas,' Ars Technica, 13 March, http://arstechnica.com/tech-policy/2008/03/gates-to-congress-microsoft-needs-moreh1-b-visas/.

Leonard, R. (1985) The Making of American Industrial Research: Science and Business at GE and Bell, 1876-1926, Cambridge: Cambridge University Press.

Lutton, J. (2015) “DARPA is spending big on big data,” FCW, 15 April, https://fcw.com/articles/2015/04/15/snapshot-data-programs.aspx

MarketsandMarkets (2015) ‘Bioinformatics Market worth \$13.3 Billion by 2020,'15 April http://www.marketsandmarkets.com/PressReleases/bioinformatics-market.asp

Marr, B. (2015) 'Google's Nest: Big Data And The Internet Of Things In The Connected Home,' Forbes, 5 August 2015,

http://www.forbes.com/sites/bernardmarr/2015/08/05/googles-nest-big-data-and-the-internetof-things-in-the-connected-home/\#55a0525458a1.

Marro, N. (2015) 'Foreign Company R\&D: In China, For China,' China Business Review, 1 June, http://www.chinabusinessreview.com/foreign-company-rd-in-china-for-china/.

McDonnell, T. (2014) 'Monsanto Is Using Big Data to Take Over the World,' Mother Jones, 19 November, http://www.motherjones.com/environment/2014/11/monsanto-big-data-gmoclimate-change.

Miller, C. (2013) ‘Geek Appeal: New York vs. Seattle,’ New York Times, 14 April, http://www.nytimes.com/2013/04/14/education/edlife/new-york-and-seattle-compete-fordata-science-crown.html?_r=0.

Mokyr, J. (2002) The gifts of Athena: Historical origins of the knowledge economy, Princeton, N.J.: Princeton University Press.

Microsoft Spent \$10.4 Billion In R\&D In 2014, Ranked 4th in The World (2014), Microsoft News, 4 December, http://mspoweruser.com/microsoft-spent-10-4-billion-in-rd-in-2014ranked-4th-in-the-world/

Mizroch, A. (2015 a) 'A Talent War in Artificial Intelligence - Tech firms, universities fund and poach experts, hoping to gain an edge in hot area of computing,' Wall Street Journal, 4 May, B1.

Mizroch, A. (2015 b) 'Artificial-Intelligence Experts Are in High Demand,' Wall Street Journal, 1 May 2015, http://www.wsj.com/articles/artificial-intelligence-experts-are-in-highdemand-1430472782.

National Science Foundation (2014 a) Science and Engineering Indicators, Research and Development: National Trends and International Comparisons, Arlington, VA: National Science Board, http://www.nsf.gov/statistics/seind14/index.cfm/chapter-4/c4s1.htm. 
National Science Foundation (2014 b) Science and Engineering Indicators, Science and Engineering Labor Force, Arlington, VA: National Science Board, http://www.nsf.gov/statistics/seind14/index.cfm/chapter-3/c3h.htm.

New IDC Forecast Sees Worldwide Big Data Technology and Services Market Growing to \$48.6 Billion in 2019, Driven by Wide Adoption Across Industries (2015) IDC, 9 November, http://www.idc.com/getdoc.jsp?containerId=prUS40560115

Noble, D. (1977) America by design: science, technology, and the rise of corporate capitalism, New York: Knopf.

Organization for Economic Co-operation and Development (2014) OECD science, technology, and industry outlook, http://www.oecd-ilibrary.org/science-andtechnology/oecd-science-technology-and-industry-outlook-2014_sti_outlook-2014en;jsessionid=6h0hml4q1fn6o.x-oecd-live-03

Organization for Economic Co-operation and Development (2015) OECD science, technology and industry scoreboard 2015, http://www.oecdilibrary.org/docserver/download/9215031e.pdf?expires=1452367087\&id=id\&accname=guest \&checksum=B527A14CB78EC4CAD0E265BF42BEA46F.

Orihuela R. and Bass, D. (2015) 'Help Wanted: Black Belts in Data,' Bloomberg Business, 4 June, http://www.bloomberg.com/news/articles/2015-06-04/help-wanted-black-belts-in-data.

Preston, J. (2015) 'Large Companies Game H-1B Visa Program, Costing the US Jobs,' New York Times, 10 November, http://www.nytimes.com/2015/11/11/us/large-companies-game-h1b-visa-program-leaving-smaller-ones-in-the-cold.html?_r=0.

Roberts, B.R. \& Berg, N. (2012) Walmart key insights and practical lessons from the world's largest retailer. London, Kogan Page.

Rosenbush S. \& Bennett, J. (2013) 'GM Opens New Data Center Modeled on Google, Facebook,' Wall Street Journal, 13 May 2013, http://blogs.wsj.com/cio/2013/05/13/gmopens-new-data-center-modeled-on-google-facebook/.

Sargent, J.F. Jr. (2013) 'Federal Research and Development Funding: FY2013,' Congressional Research Service, 5 December 5, https://www.fas.org/sgp/crs/misc/R42410.pdf

Sargent, J.F. Jr. (2015) 'Federal Research and Development Funding: FY2015,' Congressional Research Service, 2 February 2, https://www.fas.org/sgp/crs/misc/R43580.pdf.

Schiller, D. (1999) Digital Capitalism: Networking the Global Market System, Cambridge, Mass.: MIT Press.

Schiller, D. (2007) How to think about information, Urbana: University of Illinois Press.

Schiller, D. (2013) 'Pushing Informationalized Capitalism into Science and Information Technology,’ Media Development 50, 2, pp. 13-18. 
Schiller, D. (2014) Digital Depression: Information Technology and Economic Crisis, Urbana: University of Illinois Press.

Shafaeddin, M. (2012) Competitiveness and development: myth and realities, London: Anthem Press.

Shalal, A. (2015) 'The Pentagon wants at least \$12 billion to fund AI weapon technology in 2017,' Business Insider, 14 December, http://uk.businessinsider.com/the-pentagon-wants-atleast-12-billion-to-fund-ai-weapon-technology-in-2017-2015-12?r=US\&IR=T.

Shapiro, H. (1993) 'The Evolution of U.S. Science Policy, Part 1,' Princeton Alumni Weekly, 94, p. 41.

Singer, P. (2014) 'Federally Supported Innovations: 22 Examples of Major Technology Advances That Stem from Federal Research Support,' Information Technology \& Innovation Foundation, http://www2.itif.org/2014-federally-supported-innovations.pdf.

Smith, M (ed.) (1985) Military Enterprise and Technological Change: The American Experience, Baltimore: Johns Hopkins.

Sottek, T.C. (2012) 'Obama administration announces \$200 million 'big data' research and development initiative,” Verge, 29 March, http://www.theverge.com/2012/3/29/2912137/obama-big-data-research-initiative.

Specter, M. (2013) 'Why the climate corporation sold itself to Monsanto, New Yorker, 4 November, http://www.newyorker.com/tech/elements/why-the-climate-corporation-solditself-to-monsanto.

Steckel, F. (1999) 'Cartelization of the German Chemical Industry, 1918-1925,' Journal of European Economic History,19, 2, pp. 329-51.

Thomson, I. (2015) 'Safe Harbor ripped and replaced with Privacy Shield in last-minute USEurope deal,’ Register, 2 February, http://www.theregister.co.uk/2016/02/02/safe_harbor_replaced_with_privacy_shield.

Tiezzi, S. (2013) 'Huawei Officially Gives Up On The US Market,' Diplomat, 5 December, http://thediplomat.com/2013/12/huawei-officially-gives-up-on-the-us-market/.

Top 10 R\&D importing countries in the world (2015) China Daily, 11 November 11, http://usa.chinadaily.com.cn/business/2015-11/11/content_22431133.htm.

Truong, A. (2015) 'Huawei's R\&D spend is massive even by the standards of American tech giants,' Quartz, 31 March, http://qz.com/374039/huaweis-rd-spend-is-massive-even-by-thestandards-of-american-tech-giants/.

Tselichtchev, I. (2011) China versus the west the global power shift of the 21st century, Singapore: Wiley. 
US Department of Commerce (2015) '2016 Funding Highlight,' http://2010-

2014.commerce.gov/sites/default/files/documents/2015/february/omb_fact_sheet-fy16_doc_budget_chapter--1_30_final.pdf

US Department of Labor Office of Foreign Labor Certification (2014) 'H-1B Temporary Specialty Occupations Labor Condition Program - Selected Statistics,' https://www.foreignlaborcert.doleta.gov/pdf/H-1B_Selected_Statistics_FY2014_Q1.pdf

Vanni, O. (2015) 'Here Are the Schools with Degrees in Data Science,' BostInno, 15 October, http://bostinno.streetwise.co/2015/10/15/best-us-schools-for-data-science-colleges-degreesin-data-science/.

Vinik, D. (2013) 'Larry Summers Gave An Amazing Speech On The Biggest Economic Problem Of Our Time,' Business Insider, 17 November, http://uk.businessinsider.com/larry-summers-imf-speech-on-the-zero-lower-bound-201311 ? $\mathrm{r}=\mathrm{US} \& \mathrm{IR}=\mathrm{T}$.

Volkswagen Group expects new digitalization era in automobile industry (2014), Volkswagen, 9 March, http://www.volkswagenag.com/content/vwcorp/info_center/en/themes/2014/03/CeBIT.html.

Waters, R. (2016) 'Swiftkey deal highlights gulf in artificial intelligence world,' Financial Times, 5 February, http://www.ft.com/intl/cms/s/0/ab82bf82-cb5a-11e5-a8efea66e967dd44.html\#axzz3zJyNvA7x.

White House Office of the Press Secretary (2013) 'Executive Order -- Making Open and Machine Readable the New Default for Government Information,' 9 May, https://www.whitehouse.gov/the-press-office/2013/05/09/executive-order-making-open-andmachine-readable-new-default-government-.

White House Office of the Press Secretary (2015) 'FACT SHEET: The White House Releases New Strategy for American Innovation, Announces Areas of Opportunity from Self-Driving Cars to Smart Cities,' 21 October, https://www.whitehouse.gov/the-pressoffice/2015/10/21/fact-sheet-white-house-releases-new-strategy-american-innovation

Wilson, J. (2018) 'Immigration Facts; Temporary Foreign Workers,' Brookings Institute, 18 June, http://www.brookings.edu/research/reports/2013/06/18-temporary-workers-wilson.

Wood, E. (2003) Empire of Capita, London: Verso.

Worthington, C. (2015) 'Wearable Tech Goes to Washington,' Wall Street Daily, 31 August, http://www.wallstreetdaily.com/2015/08/31/pentagon-wearable-tech-military/.

Notes

\footnotetext{
${ }^{1}$ According to Gartner, a research firm, 2016 worldwide IT spending is set to reach a total of \$3.54 trillion dollars. See “Gartner Says Worldwide IT Spending is Forecast to Grow 0.6 Percent in 2016,” Gartner, January 18, 0216, http://www.gartner.com/newsroom/id/3186517.

${ }^{2}$ For a scathing critique, see N.B. Danielian, AT\&T: Story of Industrial Conquest (New York: Vanguard, 1939), 92-137.
} 


\footnotetext{
${ }^{3}$ For a perceptive early analysis, see David Dickson, The New Politics of Science (New York: Pantheon, 1984); Schiller, Digital capitalism, 143-202.

${ }^{4}$ See "Microsoft Spent $\$ 10.4$ billion in R\&D in 2014, ranked $4^{\text {th }}$ in the word," Microsoft, December 4, 2014, http://microsoft-news.com/microsoft-spent-10-4-billion-in-rd-in-2014-ranked-4th-in-the-world/.

${ }^{5}$ See more detail about the President's Council of Advisors on Science and Technology (PCAST) at White House Office of Science and Technology, “About PCAST,” https://www.whitehouse.gov/administration/eop/ostp/pcast/about.

${ }^{6}$ See the list members of PCAST at https://m.whitehouse.gov/administration/eop/ostp/pcast/about/members.

${ }^{7}$ See "Worldwide Information Technology (IT) spending forecast from 2005 to 2016," Statista, http://www.statista.com/statistics/203935/overall-it-spending-worldwide/.

${ }^{8}$ See "IT spending worldwide by vertical industry in 2014 and 2015," Statista,

http://www.statista.com/statistics/269400/global-it-spending-by-industry/. By a different tally, Banks alone spent about $\$ 188$ billion on information and communications technology in 2014. See Martin Arnold and Tom Braithwaite, “Banks Ageing IT Systems Buckle Under Strain,” Financial Times, June 18, 2015, http://www.ft.com/intl/cms/s/0/90360dbe-15cb-11e5-a58d-00144feabdc0.html\#axzz3ddkVYDr7.

9 See Coral Davenport and Danny Hakim, “US Sues Volkswagen in Diesel Emissions Scandal,” New York Time, 4 January 2016, http://www.nytimes.com/2016/01/05/business/vw-sued-justice-department-emissionsscandal.html?_r=0.

${ }^{10}$ At the same time, it's worth noting, US IT firms employing a large percentage of the scientific and technical workforce - such as Microsoft, Dell, and HP - slashed thousands of jobs in the face of a rapidly changing IT market. IBM expected to cut no less than a quarter of its global workforce.

${ }^{11}$ The National Science Foundation has analyzed S\&E employment data from the Bureau of Labor Statistics. See "What does the S\&E job market look like for US graduates?” National Science Foundation, https://www.nsf.gov/nsb/sei/edTool/data/workforce-03.html ${ }^{12}$ Ibid.

${ }^{13}$ The minimum wage for $\mathrm{H}-1 \mathrm{~B}$ workers can be as little as the so-called 17th percentile, meaning that the wage can be as low as what the 17 th-lowest wage earner out of 100 in a particular job category in a specific region would earn.

${ }^{14}$ For an illuminating discussion, above all as regards physics, see John Krige, American Hegemony and the Postwar Reconstruction of Science in Europe (Cambridge: MIT Press, 2006).

${ }^{15}$ See more detail on TPP at Office of the United States Trade Representative "Trans-Pacific Partnership: Summary of US Objectives,”, https://ustr.gov/tpp/Summary-of-US-objectives.
} 